\title{
PEMBENTUKAN DAN TRANSFORMASI CORE VALUES DI SEKOLAH ALAM
}

\author{
Fauzi \\ e-mail: fauzi@iainpurwokerto.ac.id \\ Fakultas Tarbiyah dan IImu Keguruan IAIN Purwokerto
}

\begin{abstract}
Abstrak: Penelitian dilatarbelakangi oleh fenomena keberhasilan sekolah alam dalam mewujudkan eksistensinya sebagai salah satu lembaga pendidikan alternatif di Indonesia. Keberhasilan tersebut bersumber pada kemampuannya membentuk dan mentransformasikan nilai inti (core values) yang dimilikinya. Penelitian ini bertujuan mendeskripsikan proses pembentukan dan transformasi core values yang berbasis kekhasan lingkungan dan kearifan lokal di Sekolah Alam Baturraden (SABar) yang dilakukan pada bulan Februari - Agustus 2017 di SABar yang berlokasi di hutan damar bumi perkemahan Baturraden. Pendekatan yang digunakan adalah kualitatif dengan teknik pengumpulan data observasi, wawancara, dan dokumentasi serta dianalisis dengan teknik analisis kualitatif model interaktif yang meliputi koleksi data, reduksi data, penyajian data, dan penarikan kesimpulan. Hasil kajian menunjukkan bahwa seluruh kegiatan pendidikan dan pembelajaran dilakukan dengan pendekatan holistik integratif dan menjadikan lingkungan alam hutan sebagai tempat, sumber, dan media belajar dalam rangka proses penyadaran, pencerahan, pemberdayaan, dan pembentukan karakter dan perilaku anak. Core values yang dikembangkan Sekolah Alam Baturraden berbasiskan pada lima nilai SABar yaitu soulfull, akhlak, beyond, achieve, dan responsible yang menjadi nilai khas dan branding Sekolah Alam Baturraden. Di samping itu tetap mewujudkan empat dimensi core values yang dirumuskan Jaringan Sekolah Alam Nusantara (JSAN) yakni kurikulum, metode, lingkungan, fisik, dan komunitas.
\end{abstract}

Kata-kata kunci: sekolah alam, transformasi, core values

\section{THE ESTABLISHMENT AND TRANSFORMATION OF CORE VALUES NATURE SCHOOL}

\begin{abstract}
Research background by the phenomenon of the success of the School of Nature in realizing its existence as one of the alternative educational institutions in Indonesia. The success is based on its ability to form and transform its core values. This study aims to describe the process of formation and transformation of core values based on environmental peculiarities and local wisdom in the School of Nature Baturraden (SABar). The study was conducted in February - August 2017 at SABar located within the Damar forest of Baturraden campground. This research used a qualitative approach and collected data by observation, interview, and documentation technique. The data were analyzed by the interactive model of qualitative analysis technique, including data collection, data reduction, data presentation, and conclusion drawing. This research showed that all education and learning activities are conducted by the integrative holistic approach by making the forest to a place, source, and learning media in the process of awareness, enlightenment, empowerment, character and behavior building of the children. Core values developed by Baturraden Nature School are based on five SABar values that are soulful, morals, beyond, achieve, and responsible. These values become distinctive values and differentiator with other nature schools and become a brand of Baturraden nature school. In addition, the school embodies four dimensions of core values agreed upon in the national network of nature school, which are curriculum, method, environment, physical, and community.
\end{abstract}

Keywords: nature school, transformation, core values 


\section{PENDAHULUAN}

Sistem pendidikan persekolahan (schooling system) diakui telah mampu menciptakan perubahan cepat dalam kehidupan masyarakat dan dinilai menjadi salah satu faktor penentu kemajuan suatu bangsa. Pelembagaan sistem pendidikan dalam bentuk sekolah dipandang sangat strategis untuk mempengaruhi, mengkondisikan, dan mengarahkan perkembangan peserta didik secara sistematik dan sistemik. Bahkan secara empirik, perubahanperubahan sosial secara cepat dalam berbagai aspek kehidupan terjadi berkat kontribusi dunia sekolah (Wardani, 2014).

Beberapa istilah muncul di tengah-tengah masyarakat, yaitu "madzhab sekolahan", "madzhab ijazah", dan "madzhab gelar". Sekolah dengan ijazahnya telah menjadi barang mewah dan penentu keberhasilan manusia. ljazah menjadi "tujuan" orang bersekolah, dengan ijazah manusia beranggapan sebagian terbesar masa depannya telah dapat diraih, ditemukan, bahkan ditentukan. Sekolah sangat dipercaya oleh manusia, sehingga mengakibatkan manusia rela menghabiskan bagian terbesar dari waktu, kekayaan, dan segala kemampuannya untuk bersekolah. Sementara, di tengah- tengah ekspektasi yang tinggi terhadap sekolah, keberadaan sekolah yang oleh Dewey (2009) disebut sebagai sistem pendidikan tradisional, eksistensinya semakin dipertanyakan bahkan mendapatkan kritikan dan gugatan dari para pakar dan praktisi pendidikan di dunia.

Eksistensi sekolah yang mendominasi kehidupan manusia itulah yang digugat oleh para pakar pendidikan kritis seperti Everett Reimer (1987), Paulo Freire (1984, 2000), dan Ivan Illich (2005). Sekolah yang semestinya berwajah humanis dan progresif ternyata telah tampil dengan wajah yang cenderung kaku, kapitalis, elitis, dan melahirkan produk manusia yang bersikap serba instan. Dalam kenyataannya, sekolah sampai tinggi hanya dapat dinikmati oleh kelompok tertentu dalam masyarakat. Secara khusus, Illich (2005) mengatakan bahwa kesan sekolah sebagai terbuka untuk umum sesunggunya bersifat semu atau palsu. Sekolah (sampai tinggi) sesungguhnya hanya terbuka pada yang terus menerus memperbarui surat kepercayaannya melalui retribusi (bayaran).

Di tengah kondisi dan berbagai kritikan serta gugatan atas eksistensi sekolah tersebut, sekolah alam hadir dan berkembang di Indonesia sebagai salah satu bentuk lembaga pendidikan alternatif. Sekolah alam menghadirkan sistem dan layanan pendidikan progesif sebagai alternatif pilihan model layanan pendidikan masyarakat dewasa ini untuk menjawab kegelisahan yang sebelumnya muncul. Dalam sistem pendidikan sekolah alam, esensi sekolah sebagai institusi pendidikan yang menyajikan sistem pembelajaran yang jelas dan sistematis tetap dipertahankan. Sekolah alam menghadirkan sistem pembelajaran yang berbasiskan pada pengalaman nyata dengan memanfaatkan alam sebagai sumber, tempat, dan media belajar, mengembangkan potensi peserta didik berdasarkan potensi dan keunikannya.

Keberadaan sekolah alam sebagai salah satu bentuk lembaga pendidikan (sekolah) alternatif di Indonesia yang mulai dirintis pertama kali pada tahun 1998 di Ciganjur terus mengalami perkembangan dan mendapatkan respon positif dari masyarakat. Secara kuantitas, jumlah Sekolah Alam terus mengalami perkembangan, sampai pada tahun 2016 tercatat lebih dari 2000 Sekolah Alam di berbagai daerah di tanah air. Sebagian besar diantaraya termasuk sebagai sekolah formal yang mendapatkan izin operasioal dari Dinas Pendidikan setempat (http://sekolahalam.id/alam, diunduh tanggal 5 Maret 2017). Animo masyarakat menyekolahkan anaknya ke sekolah alam juga terus meningkat. Penerimaan dan kepercayaan masyarakat terhadap sekolah alam tentu saja lahir dari proses panjang dan kesuksesan sekolah alam membangun dan mentransformasikan nilai-nilai intinya (core values) dalam seluruh aktivitas dan layanan pendidikan.

Eksistensi sekolah alam sebagai sebuah institusi baru yang menawarkan produk layanan pendidikan alternatif berkaitan dengan konsep yang berkembang di dunia perusahaan. Secara teoretik, eksistensi tersebut adalah hasil dari kemampuan membentuk dan mentransformasikan nilai inti (core values). Collins (2014) mengemukakan bahwa kesuksesan suatu perusahaan melalui beberapa generasi bermula dari adanya disiplin menerapkan core values. Core values merupakan nilai-nilai yang berupa seperangkat prinsip dasar yang tak lekang oleh waktu, yang membimbing arah langkah aktivitas. Kesuksesan perusahaan terbaik di dunia 
diatribusikan pada kemampuannya membangun core values yang solid. Perusahaan yang telah sukses berawal dari kekonsistensiannya mewujudkan core values yang solid sepanjang waktu (Pella, 2017).

Core values sangat diperlukan sebagai panduan berpikir dan bersikap tentang masa depan. Ketaatan dan kepatuhan terhadap core values memudahkan untuk menjadi produktif pada hari ini dan untuk melangkah dengan penuh percaya diri menuju rencana jangka panjang. Apabila core values sudah terinternalisasi dan terimplementasikan di dalam mekanisme kehidupan di suatu lembaga pendidikan, maka eksistensinya semakin kokoh dan produktif (Yahya, 2003).

Pandangan filsafat empirisme berpendapat bahwa pendidikan sejati berlangsung melalui pengalaman, tetapi bukan berarti semua pengalaman pada dasarnya edukatif. Pengalaman yang tidak mendidik (miss-edukatif) menjadi pengalaman yang menghambat atau menghalangi pertumbuhan pengalaman selanjutnya sehingga menumpulkan perasaan serta menyebabkan kurangnya kepekaan atau sensitivitas dan daya tanggap atau responsibilitas (Dewey, 2009). Sejalan dengan hal tersebut, dalam konsep progresivisme, pendidikan harus bernilai kebebasan. Sekolah tradisional cenderung membatasi perkembangan intelektual dan moral. Pendidikan harus dapat membantu siswa menghadapi berbagai persoalan masa kini dan masa depan. Progresivisme didasarkan pada keyakinan bahwa pendidikan harus berpusat pada anak (child centered), bukan memfokuskan pada guru atau bidang muatan (Dewey, 2009). Tujuan pendidikan menurut progresivisme memberikan keterampilan dan alat-alat yang bermanfaat untuk berinteraksi dengan lingkungan yang berada dalam proses perubahan secara terus menerus. Alat-alat yang dimaksud berupa keterampilan pemecahan masalah (problem solving) yang dapat digunakan oleh individu untuk menentukan, menganalisis, dan memecahkan masalah (Sadulloh, 2015).

Dalam konteks kehidupan, pendidikan harus dipandang sebagai proses kehidupan, sehingga sekolah harus mewakili kehidupan masa kini, kehidupan nyata dan vital bagi anak sebagaimana dijalaninya di rumah, di lingkungan tempat tinggal, atau di tempat bermain. Dalam konteks ini, eksistensi pendidikan (sekolah tradisional) dewasa ini dianggap gagal karena cenderung mengabaikan prinsip fundamental sekolah sebagai bentuk kehidupan komunitas yang senyatanya dan bersifat alami (Tilaar, 2009). Konsep pendidikan tradisional yang digambarkan Tilaar tersebut adalah situasi, kondisi, dan praksis pendidikan yang tidak ideal meski praktek tersebut masih banyak terjadi pada pendidikan persekolahan dewasa ini. Penggambaran pendidikan yang tidak mencerminkan hakikat substantif eksistensi pendidikan bagi pengembangan potensi kreatif manusia bagi peran dan fungsinya dalam pemberdayaan kehidupan dengan beragam potensi.

Keadaan tersebut memerlukan pergeseran paradigma dan praksis pendidikan menuju perubahan hakikat sustantif eksistensi pendidikan yang lebih manusiawi dan berdaya guna bagi kehidupan. Pendidikan dihadirkan untuk dapat memfasilitasi perkembangan potensi setiap individu sesuai dengan kondisi geografis, sosial, dan budaya di mana manusia itu hidup dan berinteraksi. Pembentukan dan pewarisan suatu nilai dari satu generasi ke generasi berikutnya dipandang sebagai suatu proses transformasi.

Dalam proses transformasi, pendidikan berfungsi mentransformasikan nilai-nilai yang diakui sebagai suatu yang unggul. Transformasi suatu nilai dalam perspektif pedagogik (ilmu pendidikan) menggunakan konsep teori pedagogik transformatif sebagai pedagogik pembebasan. Menurut Tilaar (2012), pedagogik transformatif merupakan pedagogik yang berkembang sesuai dengan dinamika perubahan sosial dan perkembangan individu yang terus menerus berubah, dengan demikian pedagogik transformatif merupakan pedagogik yang dinamis. Titik tolak proses transformasi adalah individu yang kreatif.

Berdasarkan paparan di atas, keberadaan sekolah alam dengan nilai-nilai inti yang dibangun dan dikembangkan sebagai upaya menghadirkan sistem layanan pendidikan alternatif adalah suatu fenomena yang menarik untuk dikaji untuk menjawab problem pendidikan yang ada. Khususnya kawasan wilayah Banyumas dengan kondisi sosiologis dan kultural yang berbeda dengan daerah-daerah lain adalah tempat sekolah alam terlebih dulu berkembang. Keberadaan Sekolah Alam Baturraden (SABar) dapat eksis dan berkembang karena ditopang oleh core values yang telah dikembangkan dan ditransformasikan.

Secara teoretik, hasil penelitian ini bermanfaat memberikan penguatan konseptual bagi eksistensi 
dan pengembangan sekolah alam di Indonesia. Formulasi tahapan pembentukan dan model-model transformasi core values yang dirumuskan dari penelitian ini akan memperkaya khazanah teoretik dalam penyelenggaraan Sekolah Alam di Indonesia sedangkan secara praktis aplikatif, hasil kajian ini dapat dijadikan contoh aplikatif dalam membentuk dan mentransformasikan core values dan acuan praktis dalam penyelenggaraan sekolah alam serta bentuk sekolah alternatif lainnya.

\section{METODE PENELITIAN}

Penelitian ini menggunakan pendekatan penelitian kualitatif. Penelitian dilakukan dengan metode studi kasus dan proses eksplorasi yang menggambarkan realitas yang ada dalam suatu komunitas beserta dinamikanya (Sugiyono, 2014) untuk mengungkap dan memahami sesuatu di balik fenomena yang belum diketahui (Strauss dan Corbin, 2003). Penelitian ini dilakukan secara intensif, terinci dan mendalam terhadap aktivitas pendidikan Sekolah Alam Baturraden (SABar) dalam membentuk, mengembangkan, dan mentransformasikan nilainilai intinya.

Penelitian dilakukan di Sekolah Alam Baturraden yang beralamat di kawasan hutan damar Bumi Perkemahan Perhutani Baturraden, Desa Kemutug Lor Baturraden Banyumas. Sekolah Alam Baturraden berada di bawah naungan yayasan Islam bernama Yayasan Masyarakat Madani Indonesia Baru. Adapun waktu penelitian dilaksanakan pada tanggal 28 Februari 2017 sampai 30 Agustus 2017.
Objek kajian dalam penelitian ini meliputi (1) sistem pendidikan dan pembelajaran Sekolah Alam Baturraden, (2) core values Sekolah Alam Baturraden, serta (3) pembentukan dan transformasi core values di Sekolah Alam Baturraden. Subjek penelitian ini terdiri dari pengurus harian yayasan, direktur Sekolah Alam, kepala TK Alam, Kepala SD Alam, fasilitator, peserta didik, wali murid, dan pihak Perhutani pengelola hutan damar Bumper Baturraden.

Teknik pengumpulan data yang digunakan adalah observasi, wawancara, dan dokumentasi. Analisis data dilakukan dengan teknik analisis kualitatif model interaktif yang meliputi koleksi data, reduksi data, penyajian data, dan penarikan kesimpulan. Proses penelitian dilakukan dalam beberapa tahapan meliputi (1) studi pendahuluan, (2) studi literatur atau studi pustaka, (3) eksplorasi, (4) pengecekan, (5) analisis data, dan (6) pelaporan.

\section{HASIL DAN PEMBAHASAN}

\section{Gambaran Umum Sekolah Alam Baturraden Sejarah berdiri}

Sekolah Alam Baturaden (SABar) berdiri pada tahun 2011 berawal dari kegelisahan Myra Safar (selanjutnya disebut Myra) selaku pendiri Sekolah Alam Baturaden pada awalnya untuk memenuhi kebutuhan akan lembaga pendidikan yang tepat untuk putrinya. Kesadaran akan kebutuhan lembaga pendidikan alternatif bagi anaknya itulah yang mendorong Myra mendirikan SABar. Myra pernah terpikir akan menerapkan home schooling pada anaknya, tetapi suaminya tidak sepakat dengan hal itu karena suami Myra yang berada dalam dunia bisnis menganggap bahwa home schooling masih memiliki kekurangan. Kekurangan tersebut misalnya dalam hal sosialisasi, interaksi dengan kehidupan nyata, manajemen konflik, membangun jaringan, dan problem solving yang tidak dapat dikembangkan dalam kehidupan nyata jika belajar melalui home schooling.

Myra beranggapan bahwa belajar tidak hanya mengandalkan pulpen dan kertas saja tetapi harus meilbatkan semua panca indra, sehingga model pendidikan yang melibatkan seluruh indera adalah metode yang tepat. Berdasarkan keyakinan itu Myra menerapkan konsep alam sebagai tempat dan sumber belajar, karena belajar dengan alam dapat melibatkan semua indera yang dimiliki oleh peserta didik secara lebih optimal. Menurut Myra terdapat pilar utama yang mampu menjadi bekal hidup yang nyata bagi anak dalam konsep belajar dengan alam yang diwujudkan dalam bentuk sekolah alam. Hal ini dikarenakan pembelajaran melalui eksplorasi bebasis pengalaman empirik. Adapun pilar yang dimaksud tersebut meliputi akhlakul karimah, logika berpikir, leadership, dan kewirausahaan.

SABar didirikan untuk memberikan kesempatan yang luas kepada anak-anak untuk 
bergerak, bereksplorasi, dan menjelajah dunia kecilnya. Anak-anak harus dibukakan wawasannya sehingga memiliki referensi pengetahuan yang kaya. Anak-anak harus dikoordinir keingintahuannya sehingga menjadi manusia yang kreatif dan berpikir out of the box.

SABar berlokasi di kawasan hutan damar milik perhutani, sehingga banyak yang mengatakan SABar itu sekolah hutan. Sekolah ini didirikan dengan semangat sebagai sekolah komunitas, maka pendirian sekolah ini menggunakan pendekatan dari akar (grass root model). Proses ini diawali dengan mengadakan komunikasi dan koordinasi dengan berbagai pihak, sosialisasi dan pertemuan dengan berbagai elemen masyarakat, mulai dari warga, tokoh masyarakat, perangkat desa, para pelaku usaha dan wisata di wilayah Baturraden serta dinas terkait.

Pendirian sekolah ini tidak mudah, karena dimulai dengan sesuatu yang baru dan terdengar asing serta di luar kebiasaan masyarakat yang terbiasa dengan sekolah di tengah pemukiman dan gedung permanen. Melalui berbagai proses penguatan nilai dan sosialisasi yang intensif akhirnya Sekolah Alam Baturraden dapat berdiri dan diterima eksistensinya oleh msyarakat dengan tempat belajar menggunakan saung semi permanen sebagai shelter dan tempat berteduh dari hujan dan panas. Secara kelembagaan SABar berdiri di bawah naungan Yayasan Masyarakat Madani Indonesia Baru.

Dalam perkembangannya, konsep dan tempat pendidikan yang khas dan unik yang berada di hutan yang dipilih oleh Myra sangat tepat. Hal ini terbukti ketika SABar baru tiga tahun operasional sudah menjadi acuan sekolah-sekolah alam lainnya yang sudah lama berdiri. Perkembangan jumlah peserta didik pun sangat pesat. Bahkan Lendo Novo sebagai orang yang pertama kali merintis sekolah alam menjadikan SABar sebagai salah satu pilot project atau sekolah percontohan yang berkonsep alam di Indonesia.

\section{Bentuk dan program layanan pendidikan}

Sekolah Alam Baturaden (SABar) merupakan bentuk pendidikan dasar alternatif yang menyelenggarakan program pendidikan berdasarkan kurikulum nasional yang diperkaya dengan kurikulum sekolah alam dengan metode Belajar Bersama Alam (BBA) berstandar Internasional. Adapun bentuk dan program layanan yang ada di Sekolah Alam Baturaden meliputi (1) TK Alam Baturaden, (2) SD
Alam Baturaden, (3) SMP Alam Baturaden, dan (4) Program Inklusi untuk anak berkebutuhan khusus (ABK).

\section{Sistem Pendidikan dan Pembelajaran Sekolah} Alam Baturraden

Sistem pendidikan di Sekolah Alam Baturraden dilakukan dengan konsep keterpaduan (pendekatan integratif). Sistem yang dikembangkan dengan berusaha mengintegrasikan antara pendidikan umum dan pembangunan karakter/akhlakul karimah; antara sekolah, keluarga dan masyarakat dengan mengoptimalkan bagian kognitif, afektif dan psikomotorik. Hal ini dilakukan dengan harapan peserta didik menjadi manusia yang cerdas, kreatif, mandiri, dan bertaqwa. Pendidikan dilakukan dengan memadukan konsep sekolah alam dalam seluruh proses pendidikannya. Semua materi yang diajarkan dirangkai dalam bingkai kearifan lokal dalam bentuk tematik. Keterpaduan tersebut meliputi aspek materi yang diajarkan, metode pembelajaran, lingkungan fisik sekolah, suasana interaksi yang diciptakan antar semua elemen pendidikan serta adanya aspek keteladanan sebagai wahana paling efektif dalam pewarisan nilai. Sistem pembelajaran di SABar dilakukan dengan menerapkan konsep pembelajaran yang berbasis pada aktivitas dan kreativitas anak dengan menjadikan alam lingkungan hutan damar bumi perkemahan Baturraden sebagai tempat, sumber, dan media belajar dengan aneka ragam sumber dayanya.

Kegiatan pembelajaran berlangsung pagi hari sampai siang hari dengan aktivitas belajar meliputi (1) pukul 07.20 siswa datang dengan dihantarkan oleh keluarganya, setelah anak-anak diturunkan dari kendaraan yang membawanya, anak-anak disapa oleh fasilitator kelas masing-masing dengan mengucapkan salam dan bersalaman, kemudian guru menyuruh anak-anak untuk duduk di depan pintu masuk SABar menunggu temannya yang sedang dijemput oleh pihak sekolah dengan menggunakan fasilitas mobil jemputan sekolah, fasilitator menanyakan apakah sudah sarapan pagi atau belum, kemudian membuka satu persatu tas anak, jika ada kotak makanan yang berisi bekal seperti nasi dan lauknya berarti anak belum sarapan, kemudian guru menyuruhnya makan atau menyuapi mereka; (2) pukul 08.30 mobil yang melakukan jemputan mulai datang, lalu guru membukakan pintu mobil dan mengucapkan salam serta menanyakan kabar anak-anak, setelah itu, guru menyuruh 
anak-anak untuk jalan menuju serambi masjid, setibanya di serambi masjid, anak-anak berkumpul jadi satu, baik itu siswa TK atau SD untuk melihat kejutan pagi (welcoming), tujuan kegiatan ini adalah menyamakan mood mereka ketika akan memulai pembelajaran, karena tidak semua anak berangkat dari rumah dengan perasaan senang, tenang, dan bangga ketika akan berangkat sekolah; (3) Kegiatan welcoming ini berupa aktivitas awal untuk kondisioning atau penyiapan kesiapan anak memulai aktivitas belajar hari itu yang dibuat menarik dan meriah agar anak ceria dan siap belajar misalnya membuat perahu yang bisa memutar di air dengan memanfaatkan tekanan udara dan bahan-bahan meliputi balon, lem tembak, styrofoam, gunting, air, ember besar, fasilitator menginstruksikan bagaimana cara membuat perahu sambil menanyakan beberapa pertanyaan kepada peserta didik, misalnya penyebab balon yang kecil kemudian bisa menjadi besar dan pertanyaan laiinya, kemudian anak mencobanya; (4) Pukul 08.00 anak mengambil wudhu untuk melaksanakan sholat Dhuha berjamaah, untuk TK sholat dilakukan di saung TK sedangkan untuk SD sholat Dhuha dilaksanakan di masjid, pelaksanaan sholat Dhuha secara berjamaah dilakukan dengan formasi satu anak laki-laki menjadi imam dan anak lainnya menjadi makmum, guru menanyakan terlebih dahulu surat yang akan dibaca untuk bacaan surat Al-Qur'an yang akan dibaca, kesepakatan menjadi kebiasaan mereka dalam menentukan pilihan yang akan dilakukan, bacaan sholat dibaca secara bersama-sama mulai dari takbir sampai salam; (5) pukul 08.30 circle time (open class) meliputi berdoa, muroja'ah, morning promise, belajar angka, menghitung dan sebagainya, kegiatan ini dimulai dengan anak-anak duduk membentuk lingkaran kecil memegang tangan temannya lalu semua anak mengucapkan janji sobat, satu-persatu mengucapkan janji misalnya akan mengikuti kegiatan dengan baik, tidak marah-marah, tidak berbuat hal yang tidak baik, dan lain-lain; (6) pukul 80.45 pembelajaran dimulai di kelas (dalam saung) atau di luar kelas dengan memanfaatkan alam mengenalkan anak akan tumbuhan sesuai temanya masing-masing; (7) pukul 09.30 - 10.00 (snack time) anak-anak menuju dapur atau kantin SABar lalu mengambil makanan ringan yang telah disediakan dengan menu makanan yang berganti-ganti setiap harinya dan tetap menggunakan konsep makanan yang alami, seperti ketela rebus, klepon, buah- buahan, dan lain-lain, anak-anak mengambil satu persatu dengan tertib dan sopan lalu menikmatinya di tempat yang disediakan serta didampingi para fasilitator, kemudian anak-anak bermain bersama di halaman samping saung; (8) pukul 10.00 11.00 anak anak masuk ke kelas masing-masing melaksanakan pembelajaran bersama guru kelas dengan aktivitas belajar yang berbeda, misalnya di kelas venus pembelajarannya membuat planet (tata surya) menggunakan koran bekas yang diremas-remas membentuk bola, sedangkan di kelas lainya guru membacakan cerita anak dan anak mendengarkan dengan penuh keseriusan; (9) pukul 11.00 - 11.15 adalah kegiatan tutup kelas atau refleksi yang mengikat makna-makna selama pembelajaran, guru mendengarkan cerita anak tentang pengalamannya memecahkan masalah atau sebagainya; (10) pukul 11.15 - 12.00 anak-anak pergi menuju dapur untuk makan siang dengan menu telur goreng dan sayuran, anak-anak dibiasakan mencuci tangan lalu mengambil piring dan mengantri mengambil makanan, setelah selesai makan anakanak mencuci tangan dan membersihkan piring tempat makan lalu mengambil tas dan berkemas untuk pulang, berjalan menuju tempat parkir mobil jemputan fasilitas sekolah.

\section{Core Values Sekolah Alam Baturraden Lima nilai SABar}

Core values yang dikembangkan di SABar mengacu pada empat pilar pokok yang dirancang oleh Jaringan Sekolah Alam Nasional (sumber: http://sekolahalam.id/alam) yaitu (a) kurikulum (curriculum), core values-nya adalah akhlak dan leadership, bakat dan lifeskill, seni dan kreativitas, lingkungan dan konservasi, logika dan akademika (logic and academic); (b) metode (method), core values-nya adalah belajar dengan alam (learning with nature), bahasa ibu (mother language), outbond, magang (intership), belajar dari ahlinya (learn from maestro); (c) lingkungan dan fisik (environment and physic), core values-nya adalah bersih (clean), hijau dan berkelanjutan (green and sustainable), berbiaya rendah (low cost); (d) komunitas (people), core valuesnya adalah keterlibatan semua elemen (sekolah, pemerintah, dan orang tua), serta partisipatif dan kontributif (partisipative and contributive), karakter unggul (noble character).

Empat pilar nilai di atas oleh Sekolah Alam Baturraden dalam implementasinya menjadi dasar pengembangan seluruh aktivitas pendidikan dan 
menjadi dasar pengembangan lima nilai inti (core values) yang menjadi orientasi dasar dan kekhasan SABar, yaitu meliputi soulfull, akhlak, beyond, achive, dan responsible. Kelima kata ini jika disingkat menjadi kata SABar yang sekaligus singkatan dari Sekolah Alam Baturraden.

Makna lima nilai dasar Sekolah Alam Baturraden (Sumber: Profil Sekolah Alam Baturaden) adalah (1) soulfull (memiliki jiwa), artinya setiap kegiatan yang dilakukan di SABar memiliki jiwa dan semangat serta alasan yang tepat mengapa kegiatan tersebut dilakukan, jiwa dari setiap kegiatan harus berdasar kepada Al-Qur'an sebagai pedoman hidup dan mengikuti As-Sunah sebagai tuntunan yang dicontohkan oleh Rasulullah SAW; (2) akhlak, setiap insan yang ada di SABar senantiasa meningkatkan kualitas akhlak pribadi, akhlak saudaranya, dan akhlak anak-anak didiknya sehingga menjadi manusia yang mulia dengan semangat bahagia dunia bahagia dan akhirat surga; (3) beyond (lebih dari standar), setiap kegiatan yang dilakukan di SABar haruslah melebihi standar umum yang ada, hal ini mengisyaratkan bahwa SABar ingin melakukan yang terbaik dalam setiap langkah yang diambilnya; (4) achive (mencapai sesuatu), ketika SABar senantiasa melakukan yang terbaik, terpatri sebuah tekad untuk mencapai prestasi-prestasi terbaik yang membuat SABar selalu di depan; serta (5) responsible (tanggung jawab), setiap insan yang ada di SABar melaksanakan living value ini dengan penuh tanggung jawab sebagai wujud manusia yang berakhlak mulia.

\section{Pengembangan dan integrasi empat dimensi} Core Values JSAN dalam SABar

Sebagai bagian dari Jaringan Sekolah Alam Nusantara (JSAN), SABar juga membangun, mengembangkan, dan mentransformasikan empat dimensi atau bidang core values yang dikembangkan oleh JSAN dalam pendidikan di SABar meliputi kurikulum, metode, lingkungan dan fisik, komunitas. Keempat core values itu menjadi rujukan pendidikan pada seluruh sekolah alam se-nusantara dengan pengembangan dan implementasi sesuai dengan situasi, kondisi, dan kekhasannya masing-masing (sumber: Dokumen Penyelenggaraan Sekolah Alam). Pengembangan dan perwujudan empat dimensi core values sekolah alam yang dikembangkan oleh Sekolah Alam Baturraden adalah kurikulum, metode, lingkungan fisik, dan komunitas (Sumber: Profil Sekolah Alam Baturaden).
Kurikulum pendidikan SABar menggunakan konsep kurikulum belajar bersama alam dengan pendekatan terpadu yang mengikuti standar pendidikan nasional didasarkan pada potensi, kemampuan, dan kebutuhan anak didik yang disesuaikan dengan potensi lokal daerah dimana sekolah itu berada. Dalam implementasinya, pembelajaran dilakukan dengan berbasis tema (pembelajaran tematik). Model pengembangan tema menggunakan model jaring laba-laba (spider $w e b$ ) dengan pusatnya berupa tema yang dipelajari dan cabang sebagai sebaran materi. Spider web kemudian dijabarkan dalam bentuk semester plan (rencana semester), weekly plan (rencana mingguan), dan daily plan (rencana harian).

Kurikulum Sekolah Alam Baturraden sudah memenuhi standar kurikulum yang ditetapkan Kementerian Pendidikan dan Kebudayaan RI yang memuat sembilan sebaran materi dari penjabaran empat pilar dimensi nilai meliputi kurikulum Falsafah IImu Pengetahuan, Kurikulum Akhlakul Karimah Building, Kurikulum Leadership, Kurikulum Enterpreunership. Rincian muatan kurikulum Sekolah Alam Baturraden adalah (1) Kurikulum Falsafah Ilmu Pengetahuan yang meliputi (a) Science and Technology yang memuat materi tentang ilmu alam (fisika, kimia, dan biologi) baik secara teori atau praktek (penerapannya) dengan harapan agar siswa memiliki pemahaman yang baik tentang lingkungan sekitarnya secara logis, sehingga siswa merasa bahwa seluruh kejadian di dunia ini adalah suatu proses dan siswa dapat menciptakan teknologi tepat guna yang bermanfaat; (b) Mathematics yang dirancang untuk menstimulasi logika berfikir dan kemampuan mengolah angka, sehingga siswa dapat mengaplikasikannya dalam kehidupan sehari-hari; (c) Language yang meliputi Bahasa Indonesia, Bahasa Jawa, dan Bahasa Inggris serta kurikulum language ini ada agar secara teknis siswa dapat menggunakan bahasa sebagai alat komunikasi dalam kehidupannya; (d) Socio-Culture and Fine Art yang meliputi ilmu menjalin hubungan dan bersosialisasi, sikap baik dalam hubungannya dengan orang lain sebagai anggota dari lingkungan sosial dan kewarganegaraan, dan seni dan kemudian ilmu seni mencakup seni rupa, seni lukis, dan seni musik; (2) Kurikulum Akhlakul Karimah Building yang meliputi (a) Aqidah Akhlak yang menuntut materi tentang pemahaman siswa terhadap Allah (akidah), cara bersikap baik (akhlak); (b) Al-Qur'an dan Hadist; 
(c) tata cara ibadah (figh); (d) sejarah kebudayaan Islam (tarikh), melalui kurikulum ini diharapkan siswa mendapat gambaran menyeluruh bahwa segala sesuatu yang ada dan terjadi di dunia adalah rencana dan keputusan Allah; (e) library and audio visual yang memuat ilmu-ilmu tentang perpustakaan dan multmedia untuk menumbuhkan kecintaan terhadap buku serta menstimulus kemampuan siswa untuk dapat melakukan presentasi; (3) Kurikulum Leadership dan Kewirausahaan yang meliputi (a) Outbound and Physical Movement yang memuat materi-materi pendidikan karakter (character building) dan kesehatan jasmani; (b) Business and Tourism yang dirancang untuk menstimulasi jiwa kepemimpinan dan kewirausahaan siswa sehingga diharapkan siswa dapat memahami kecakapan dasar keramahtamahan (hospitality); serta (c) Environmental Awareness yang dirancang untuk menumbuhkan kesadaran siswa terhadap lingkungan sekitarnya agar memiliki pola dan gaya hidup hijau (green life style).

Metode pembelajaran yang digunakan pada Sekolah Alam Baturraden adalah (1) tauladan, yaitu memberikan contoh aplikatif; (2) pembiasaan, yaitu "bisa karena biasa" tanpa membebani; (3) outing dan riset, yaitu melakukan pengamatan terhadap kondisi dan fenomena alam, budaya dan masyarakat; (4) outbound, yaitu permainan/atraksi high/low impact, tracking (lintas alam), caving (menyusuri gua) guna membangun mentalitas peserta didik; (5) magang, yaitu menginteraksikan peserta didik dengan unit, pelaku lingkungan bisnis; (6) belajar dari ahlinya, yaitu digunakan untuk melatih serta meneladani etos dan sikap dalam setiap aktivitas; dan (7) bahasa ibu, yaitu sebagai istilah dimaksud itu adalah istilah untuk komunikasi kasih sayang.

Lingkungan dan fisik Sekolah Alam Baturraden mengambil arsitektur lanskap gunung dan hutan yeng menjadi kekayaan alam daerah Baturraden dan sangat kondusif untuk eksplorasi, pembelajaran dan petualangan siswa. Lokasi Sekolah Alam Baturraden yang digunakan untuk tempat pendidikan Taman Kanak-kanak dan Sekolah Dasar adalah di petak 38-g (seluas 2,3 Ha) di wilayah kerja $\mathrm{KPH}$ Banyumas Timur yang merupakan pangkuan dari Lembaga Masyarakat Desa Hutan (LMDH) Wana Karya Lestari, Desa Kemutug, Lor Kecamatan Baturraden, Kabupaten Banyumas Provinsi Jawa Tengah.

Lokasi di Petak 38-g dipilih karena sesuai dengan tingkat pendidikan yang dibangun pertama kali oleh Sekolah Alam Baturraden yaitu tingkat Taman Kanak-kanak dan Sekolah Dasar yang tingkat eksplorasinya masih terbatas dan masih membutuhkan pengawasan ekstra ketat sehingga dibutuhkan lokasi hutan yang masih cukup dekat dengan fasilitas kesehatan dan fasilitas umum lainnya. Berdasarkan hasil wawancara dengan pengelola sekolah alam diketahui bahwa pemilihan lahan disesuaikan karena tidak boleh sembarangan dalam membangun bangunan yang akan digunakan untuk keperluan di Sekolah Alam Baturraden. Hanya masjid yang bangunannya dibuat permanen sedangkan seperti kantor, saung, dapur dan lain sebagainya dibuat semi permanen dengan bahan utama kayu. Adapun lokasi kawasan Sekolah Alam Baturraden berstatus milik perhutani kawasan hutan damar yang disewakan kepada Sekolah Alam Baturraden.

Berdasarkan hasil wawancara yang penulis lakukan dengan Myra selaku pengurus harian yayasan diperoleh informasi bahwa values yang ada di Sekolah Alam Baturraden (SABar) tidak hanya diperuntukan bagi peserta didik saja, tetapi diperuntukan juga bagi pendidik (fasilitator) dan orang tua peserta didik. Khusus bagi orang tua yang menyekolahkan anaknya di SABar diperlukan kekuatan nilai, karena menyekolahkan anak merupakan perjuangan yang sangat tinggi. Sebelum masuk diadakan seleksi orang tua yaitu wawancara atau screening untuk meyakinkan orang tua bahwa di SABar orang tua harus siap direpotkan, harus ada partisipasi orang tua dalam belajar, dan memberikan pemahaman pada orang tua bahwa mendidik dan mengajar anak tidaklah mudah sehingga butuh kesungguhan dan ketulusan.

Pembentukan dan Transformasi Core Values di Sekolah Alam Baturraden

Tahap knowing (membangun pengetahuan adalah berupa tahap awal menemukan dan membangun ide atas nilai ini yang akan dibentuk dan dikembangkan. Sejak awal pendirian, para penggaagas SABar berkeyakinan bahwa membangun sekolah alam harus dimulai dari membentuk values. Proses menemukan ide/gagasan akan nilai dilakukan oleh para penggagasnya dengan melakukan proses belajar secara teoretik dan empirik dengan melihat dan terlibat langsung dalam penyelenggaraan sekolah alam.

Secara teoretik, basis pembentukan ide 
tentang nilai yang dikembangkan berlandaskan pada hasil belajar dan diskusi dengan mengacu pada ide-ide para pakar tentang konsep pendidikan alternatif yang mampu mengoptimalkan potensi anak. Rujukan utamanya adalah konsep empat pilar nilai sekolah alam yang dirumuskan oleh Lendo Novo pendiri sekolah alam pertama di Indonesia dan telah dipraktikkan di sekolah alam di Bogor. Empat pilar nilai tersebut adalah pengembangan akhlak, pengembangan logika, pengembangan sifat kepemimpinan, pengembangan mental bisnis. Nilai-nilai tersebut dibreakdown menjadi core values di Sekolah Alam Baturraden yang khas SABar yang meliputi soulfull, akhlak, beyond, achive, responsible yang merupakan nilai inti sebagai kekuatan dasar Sekolah Alam Baturraden.

Tahap acting (tahapan pelaksanaan) dibagi lagi menjadi beberapa tahapan, yaitu pertama, tahapan perumusan dan pengembangan, diawali dengan merumuskan core values saat awal pendirian oleh para penggagas dan pendiri SABar, dalam perkembangannya perumusan dalam konteks ini lebih dimaknai sebagai aktivitas pengembangan nilai dalam rangka peningkatan mutu secara terus menerus (continus quality improvement), secara konseptual, nilai inti yang telah dirumuskan tidak dilakukan perubahan secara fundamental, namun dilakukan evaluasi pada aspek implementasi dan ketercapaiannya yang selanjutnya dilakukan perumusan dalam rangka pengembangan.

Secara teknis, pelaksanaan perumusan dalam rangka pengembangan core values di SABar dikoordinasikan oleh bagian penelitian dan pengembangan (litbang yang terdiri dari pengurus harian yayasan, direktur sekolah alam, dan kepala sekolah di Sekolah Alam Baturraden).

Sekolah secara berkelanjutan akan membuat konsep-konsep rumusan konseptual dan aplikatif termasuk rencana tindakan core values, kegiatan pelaksanaan perumusan core values dilakukan di forum tahunan yang diselenggarakan pada setiap akhir tahun pembelajaran atau dalam rangka mempersiapkan masuk tahun pembelajaran baru dengan kegiatan meliputi (a) tahap persiapan yang diawali dengan pembentukan tim pada masingmasing satuan pendidikan, setiap kepala sekolah dan fasilitatornya diberi tugas merumuskan hasil evaluasi dan merumuskan konsep pengembangan core values yang meliputi soulfull, akhlak, beyond, achive, dan responsible untuk masing-masing jenjang layanan pendidikan, untuk proyek selama satu tahun, hasil rumusan tim ini akan dijadikan bahan yang akan dibahas dan menjadi program untuk satu tahun pelajaran; (b) tahapan pelaksanaan yang dimulai dengan tadarus Alquran bersama oleh para kepala sekolah dan fasilitatornya sebagai aktivitas untuk membangun nilai spiritual bagi seluruh elemen di SABar dilanjutkan dengan penyampaian penjelasan yang dipimpin oleh direktur sekolah alam dan pengurus yayasan harian kepada kepala sekolah mulai dari TK, SD, SMP, Program Inklusi dan para fasilitator baik jenjang TK, SD, SMP, dan Program Inklusi yang diarahkan untuk menyampaikan hasil capai dan hasil evaluasi kinerja dalam satu tahun dan arah target yang harus dicapai pada tahun berikutnya beserta kiat trategi yang akan dilakukan, dilanjutkan dengan masing-masing tim memisahkan diri berdasarkan kelompok tugas di masing-masing jenjang layanan pendidikan dan melakukan kerja kelompok untuk membahas paparan tim manajemen SABar dan bahan yang telah disiapkan sebelumnya untuk dijadikan rumusan kerja tim masing-masing jenjang pendidikan, hasil diskusi dan rumusan kerja masing-masing tim dipresentasikan dalam forum di hadapan jajaran manajemen; (c) tahap perumusan hasil adalah kegiatan akhir yang dilakukan dengan merumuskan hasil akhir berdasarkan masukan dan diskusi dalam forum yang selanjutnya ditetapkan sebagai program pengembangan kegiatan berbasis core values.

Kedua, tahapan sosialisasi dan membangun pemahaman, adalah tahapan yang bertujuan untuk memberikan pemahaman atas nilainilai inti yang dikembangkan oleh SABar pada seluruh elemen yang terlibat dalam proses dan penyelenggaraan pendidikan di SABar, proses sosialisasi dan membangun pemahaman atas nilai-nilai inti dilakukan berbasis pada tiga kegiatan yakni pembelajaran, interaksi keseharian, dan kegiatan layanan pendidikan, proses pemahaman nilai-nilai berbasis pada pembelajaran terutama dilakukan oleh guru atau fasilitator kepada para peserta didik dalam seluruh kegiatan pembelajaran yang alam interaksi keseharian seluruh pihak yang terlibat dalam kegiatan pendidikan mulai anak datang sampai kegiatan belajar berakhir sehingga nilai-nilai inti SABar dipahami oleh seluruh elemen yang ada di SABar, dalam hal layanan, para pengurus dan pengelola sabar secara terus menerus mensosialisasikan melalui layanan yang 
diberikan kepada para pengguna dan stakeholder termasuk kepada tamu yang hadir tentang nilainilai dan semangat yang dijadikan sebagai visi dan kekuatan pendidikan di SABar, pemahaman nilainilai inti kepada orang tua murid dilakukan dengan cara rapat rutin bulanan yang diselenggarakan oleh pihak sekolah, rapat bulanan dilakukan sebagai media dan forum komunikasi dan koordinasi antara pihak sekolah dengan para wali murid serta sebagai media penyampaian progress report capaian pendidikan secara periodik dengan orang tua untuk saling memberikan feedback atas tumbuh kembang anak, proses ini dilakukan secara terus-menerus sehingga pemahaman orang tua akan nilai-nilai yang selalu dikembangkan SABar akan terpahami dengan optimal.

Tahapan perwujudan adalah kegiatan yang dilakukan setelah selesai membuat ide-ide yang menjadi core values yang akan digunakan dalam jangka panjang. Perwujudan dilakukan dalam seluruh tata laku kegiatan meliputi pendidikan, pembelajaran, dan layanan pendidikan lainnya. Perwujudan core values melibatkan pengelola, para fasilitator, peserta didik, orang tua peserta didik, dan seluruh stakeholder lainnya.

Tahap perwujudan dibagi lagi menjadi beberapa tahapan, yaitu (1) perencanaan yang secara teknis dalam kegiatan pembelajaran diwujudkan mulai dari penyusunan rencana pembelajaran khususnya dalam pengembangan konten pembelajaran dibentuk dengan teknik jaring laba-laba (spider web) dengan pusatnya berupa tema yang dipelajari dan cabang sebagai sebaran materi, kemudian dijabarkan dalam bentuk semester plan (rencana semester), weekly plan (rencana mingguan), daily plan (rencana harian); (2) pelaksanaan, pengaturan waktu untuk kegiatan pembelajaran peserta didik selama satu tahun pelajaran di Sekolah Alam Baturraden disebut dengan kalender pendidikan yang terinci seperti terlihat pada Tabel 1.

Tabel 1

Kalender Pendidikan SABar

\begin{tabular}{cccc}
\hline No. & Kegiatan & Alokasi Waktu & Keterangan \\
\hline 1. & Pembelajaran efektif & 40 pekan & $\begin{array}{l}\text { Digunakan untuk melak- } \\
\text { sanakan pembelajaran } \\
\end{array}$ \\
& & efektif sesuai dengan tema \\
\hline
\end{tabular}

\begin{tabular}{|c|c|c|c|}
\hline No. & Kegiatan & Alokasi Waktu & Keterangan \\
\hline 2. & $\begin{array}{l}\text { Rapat awal triwulan } \\
\text { (pemaparan program keg- } \\
\text { iatan per triwulan masing- } \\
\text { masing kelas) }\end{array}$ & $4 \times 1$ hari & $\begin{array}{l}\text { Dilakukan setiap } 3 \text { bulan } \\
\text { sekali (sebelum masuk } \\
\text { triwulan baru) }\end{array}$ \\
\hline 3. & $\begin{array}{l}\text { Penyerahan rapor (prog- } \\
\text { ress report) }\end{array}$ & $4 \times 1$ hari & $\begin{array}{l}\text { Dilakukan setiap } 3 \text { bulan } \\
\text { sekali (setelah evalusi ten- } \\
\text { gah semester dan setelah } \\
\text { evaluasi akhir semester) }\end{array}$ \\
\hline 4. & $\begin{array}{l}\text { Kegiatan khusus Seko- } \\
\text { lah Parents Day (orang } \\
\text { tua mengajar di kelas } \\
\text { putranya) }\end{array}$ & $2 \times 1$ tahun & $\begin{array}{l}\text { Dilakukan setiap } 6 \text { bulan } \\
\text { sekali }\end{array}$ \\
\hline 5. & Sekolah malam & $2 \times 1$ tahun & $\begin{array}{l}\text { Dilakukan setiap } 6 \text { bulan } \\
\text { sekali }\end{array}$ \\
\hline 6. & HUT RI & $1 \times 1$ tahun & $\begin{array}{l}\text { Dilakukan setiap } 1 \text { tahun } \\
\text { sekali }\end{array}$ \\
\hline 7. & Idul Adha & $1 \times 1$ tahun & $\begin{array}{l}\text { Dilakukan setiap } 1 \text { tahun } \\
\text { sekali }\end{array}$ \\
\hline 8. & Parenting & $4 \times 1$ tahun & $\begin{array}{l}\text { Dilakukan setiap tri wulan } \\
\text { sekali, sebelum atau sesu- } \\
\text { dah progress report }\end{array}$ \\
\hline 9. & $\begin{array}{l}\text { Assembly Program } \\
\text { (lelang hasil karya anak } \\
\text { atau pertunjukan bakat } \\
\text { anak) }\end{array}$ & $2 \times 1$ tahun & $\begin{array}{l}\text { Dilakukan } 2 \text { kali setiap } \\
\text { tahun yaitu setiap akhir } \\
\text { semester ganjil dan genap }\end{array}$ \\
\hline 10. & $\begin{array}{l}\text { Peringatan Hari Syndro- } \\
\text { ma Down } \\
\text { (kegiatan seminar inklusi) }\end{array}$ & $1 \times 1$ tahun & $\begin{array}{l}\text { Dilakukan } 1 \text { kali setiap } \\
\text { tahun }\end{array}$ \\
\hline 11. & Peringatan Hari Kartini & $1 \times 1$ tahun & $\begin{array}{l}\text { Dilakukan } 1 \text { kali setiap } \\
\text { tahun }\end{array}$ \\
\hline 12. & Peringatan Hari Bumi & $1 \times 1$ tahun & $\begin{array}{l}\text { Dilakukan } 1 \text { kali setiap } \\
\text { tahun }\end{array}$ \\
\hline 13. & Peringatan Hari Buku & $1 \times 1$ tahun & $\begin{array}{l}\text { Dilakukan } 1 \text { kali setiap } \\
\text { tahun }\end{array}$ \\
\hline 14. & $\begin{array}{l}\text { Parenting Out Bound } \\
\text { (kegiatan parenting dan } \\
\text { outbound untuk orang tua) }\end{array}$ & $1 \times 1$ tahun & $\begin{array}{l}\text { Dilakukan } 1 \text { kali setiap } \\
\text { tahun }\end{array}$ \\
\hline 15. & $\begin{array}{l}\text { Pentas akhir tahun } \\
\text { (kegiatan pentas akhir } \\
\text { tahun anak-anak) }\end{array}$ & $1 \times 1$ tahun & $\begin{array}{l}\text { Dilakukan } 1 \text { kali setiap } \\
\text { tahun }\end{array}$ \\
\hline
\end{tabular}

Tahap habituating (tahapan membangun kebiasaan) adalah proses mewujudkan kebiasaan atau budaya nilai dilakukan dengan berbasis pada tiga hal yakni kurikulum dan pembelajaran, aktivitas dan interaksi keseharian, serta tata kelola dan sistem layanan. Proses pemahaman nilai-nilai berbasis pada kurikulum dan pembelajaran terutama diberikan kepada para peserta didik dilakukan oleh para pendidik atau fasilitator. Dalam aktivitas dan interaksi keseharian dilakukan dengan semangat dan motivasi agar seluruh nilai-nilai inti SABar menjadi basis pemahaman dan aktivitas seluruh elemen yang ada di SABar. Adapun dalam hal tata kelola dan sistem layanan, para pengurus dan pengelola 
SABar melakukannya dengan pemahaman yang prima akan pentingnya mewujudkan nilai-nilai inti yang dibangun oleh SABar sehingga akan lahir budaya layanan prima dan kepuasan pelanggan.

\section{PENUTUP}

\section{Kesimpulan}

Kesimpulan hasil peneilitian adalah pertama, sistem pendidikan yang dikembangkan oleh SABar berbasiskan pada konsep bahwa setiap peserta didik unik, khas, dan memiliki potensi unggul yang dapat berkembang secara optimal jika mendapatkan layanan pendidikan yang tepat.

Kedua, seluruh kegiatan pendidikan dan pembelajaran dilakukan dengan pendekatan holistik integratif dengan menjadi alam sebagai tempat, sumber dan media belajar dalam rangka proses penyadaran, pencerahan, pemberdayaan, dan pembentukan karakter dan perilaku anak.

Ketiga, core values yang dikembangkan Sekolah Alam Baturraden berbasiskan pada lima nilai SABar yakni soulfull, akhlak, beyond, achieve, dan responsible yang secara khusus menjadi kekhasan dan pembeda nilai inti dengan sekolah alam lainnya sekaligus menjadi branding dari Sekolah Alam Baturraden. Di samping itu tetap mewujudkan empat dimensi core values yang disepakati dalam JSAN yakni kurikulum, metode, lingkungan dan fisik, dan komunitas.

Keempat, proses pembentukan dan transformasi core values dilakukan dengan melibatkan seluruh elemen dan stakeholder secara partisipatif dan kontinu baik melalui forum khusus maupun melalui aktivitas sehari-hari dalam sistem layanan pendidikan SABar.

Kelima, tahapan yang dilakukan dalam rangka pembentukan dan transformasi core values di SABar meliputi tahapan membangun pemahaman (knowing), tahapan pelaksanaan (acting), dan tahapan membangun kebiasan (habituating).

\section{DAFTAR PUSTAKA}

Baharudin. (2014). Gagasan Ivan Illich tentang pendidikan dalam buku deschooling society. Terampil, 2(2), 118-151. http://download. portalgaruda.org/article. php?article $=298$ $593 \&$ val $=5993 \&$ title $=$ GAGASAN $\% 20 \% 20$ IVAN\%20ILLICH\%20\%20TENTANG\%20 PENDIDIKAN\%20Dalam\%20Buku\%20 DESCHOOLING\%20SOCIETY

Collins, J. (2014). Good to great. Jakarta: Gramedia Pustaka Utama.

Dewey, J. (2009). Pendidikan dasar berbasis pengalaman. Yogyakarta: I Publishing.

Freire, P. (1984). Pendidikan sebagai praktek pembebasan, terjemahan Alois A. Nugroho. Jakarta: Gramedia.

Freire, P. (2000). Pendidikan kaum tertindas. Jakarta: LP3ES. Diakses dari http://sekolahalam.id/ alam.

Illich, In. (2005). Bebaskan masyarakat dari belenggu sekolah. Jakarta: Yayasan Obor Indonesia.

Pella, D.A. (2008). Semuanya bermula dari core values. Diakses melalui https://darminpella. wordpress.com.

Reimer, E. (1987). Sekitar eksistensi sekolah: Sebuah essay tentang alternatif-alternatif pendidikan. Saduran M. Soedomo. Yogyakarta: Hanindita. Sadulloh, U. (2015). Pengantar filsafat pendidikan. Bandung: Alfabeta.

Safar, M. (2015). Sekolah di atas awan. Bandung: Thabi' Press.

Strauss, A., dan Corbin, J. (2003). Dasar-dasar penelitian kualitatif. Yogyakarta: Pustaka Pelajar.

Sugiono. (2014). Metode penelitian. Bandung: Alfabeta.

Tilaar, H.A.R. (2009). Kekuasaan dan pendidikan: Manajemen pendidikan nasional dalam pusaran kekuasaan. Jakarta: Rineka Cipta.

Tilaar, H.A.R. (2012). Perubahan sosial dan pendidikan: Pengantar pedagogik transformatif untuk Indonesia. Jakarta: Rineka Cipta.

Wardani, IG.A.K., dkk. (2014). Perspektif pendidikan $S D$. Jakarta: UT Press.

Yahya, A. (2003). Great spirit, grand strategy corporate philosophy, leadership architecture, and corporate culture for sustainable growth. Jakarta: Gramedia. 